The Geographical Journal of Nepal

Vol. 13: 1-28, 2020

Doi: http://doi.org/10.3126/gjn.v13i0.28133

Central Department of Geography,

Tribhuvan University, Kathmandu, Nepal

\title{
Changing forest coverage and understanding of deforestation in Nepal Himalayas
}

\author{
Prem Sagar Chapagain ${ }^{1 *}$ and Tor H. Aase $^{2}$ \\ ${ }^{1}$ Professor, Central Department of Geography, Trubhuvan University, Kathmandu. \\ ${ }^{2}$ Professor, Department of Geography, University of Bergen, Norway.
}

(*Corresponding Author: ps.chapagain@gmail.com)

Received: 15 September 2019; Accepted: 15 December 2019; Published: March 2020

\begin{abstract}
The environmental situation of the Himalayas is a matter of global concern. Understanding on Himalayas environment is usually shaped by the changing views expressed by research institutions, donor organizations, and finally by politics and power relations. In line with changing paradigms in knowledge-producing institutions, different understandings of environmental challenges in the Himalayas have emerged. Based on the literature and available data, we have tried to discern changes in forest policies, their implication on forest management and various understandings on deforestation in Nepal Himalayas that are silent in the scientific literature. The debate of deforestation/degradation on the state of Himalayan environment came on the global agenda in the 1950s. The initial focus was on population growth and pressure on natural resources. It was followed by attention to processes of development and physical interventions in a fragile environment. Most recently local participation and poverty alleviation have been high on the agenda. In this context, the present paper attempts to examine the debates in the light of recent events and circumstances related to environmental processes in general and forest management of Nepal in particular.
\end{abstract}

Key words: Nepal Himalayas, forest management, deforestation, vicious circle, dynamic, fragile, poverty, governance 


\section{Introduction}

Himalaya is a part of the global ecosystem and a source of freshwater to 20 percent of the earth's population (Molden et al., 2016; Scott et al., 2019). Moreover, the region provides several eco-system services to the people of the mountains and the beyond. It is thus reasonable to state that the health of the Himalayan environment is a matter of global concern. This was acknowledged as early as the 1950s when the international discourse on Himalayan environmental challenges took off in the wake of UN concerns over desertification (Gurung, 1981). Since then there has emerged a number of studies on deforestation and Himalayan environmental degradation. Literature related to legal provisions, environment and development, and changing forest coverage and management aspects reveal that studies published in certain periods tend to revolve around some central conceptions of magnitude and causes of deforestation. Nepal's forest situation has passed through forest nationalization from 1957 to around 1990 and community management after 1990. These changes in forest management have various impacts on forest coverage about which different debates emerged and became prominent over a certain period of time which are not adequately examined and analysed. This paper examines the various legal provisions related to forest and further examines the changing forest coverage in relation to the changing demography and migration pattern of the country. Finally, a critical review of the various debates on deforestation and degradation that persisted over a specific time and guided the development policy of the country, is presented.

\section{Methods and materials}

This article is based on extensive review of different types of literature, and data on forests and demography of Nepal which is refered to Nepal Himalayas in this paper. The literature includes government policy documents; forest acts and regulations; and publications on forest degradation. We have first reviewed the forest sector related policy and different forest acts and regulations, including a review of existing forest management systems before the first forest act of 1957, to the successive acts and regulations. Subsequently, the changing forest management regimes are analysed in relation to actual forest coverage, starting before the first Forest Act was introduced in 1957.

In addition to reviewing those documents, we have collected available forest coverage data from 1963-64 to the latest forest survey data of 2015. We have also reviewed the methods of forest assessment adopted in various forest surveys. Furthermore, we have collected demographic data of Nepal on population size, growth rate, and migration 
pattern from 1952-54 to the latest 2011 census. We have also collected and analyzed community forestry in terms of its area and number of forest user groups.

Finally, we try to see the changing forest situation from different points of view specifically with reference to the changes in forest policy since 1950s until today. There are various explanations on deforestation that each revolves around major shifts in policy and development approach that to a large degree have shaped the debate. The explanations overlap and are not strictly delimited to the specific periods indicated. A rough timeline is constructed in order to capture the major shifts in approach and explanation of deforestation. Lastly, we illuminate shortcomings of the debate with regard to understanding the present situation.

\section{Forest management policies and acts}

The government of Nepal has been trying to manage its forest area through various acts and policies since the beginning of the systematic effort of development planning that was initiated with the first Five-Year Development Plan (1956-61). Since then various forest acts and laws have been promulgated in the country. The Private Forest Nationalization Act 1957 is the first forest act of Nepal. It was promulgated after the establishment of the democratic system in 1951. Before 1951, the country was ruled by hereditary Rana rulers for 104 years. During Rana period forest was an open access resource. Rana rulers had distributed a large forest area of Tarai region to their family members known as Birta system. Rana rulers also granted forest to high ranking government employees which is known as Jagir ownership and such land could be used for any purpose during their service period without paying any taxes to the government (Regmi, 1976).

The forest act of 1957 nationalized all forests in the country. It imposed strict ban on forest encroachment and the cutting of trees. Government became the sole owner of all private and communal forest in the country. In support to this act, the Birta Abolition Act came in 1959 that declared the forest land under Birta and Jagir ownership as national property. After one decade of the establishment of the democratic system, a partyless Panchayat System was declared in 1961. A new forest act - The Forest Act of 1961 - was promulgated. The act had i) divided forests into different categories, ii) defined the duties and authority of the forest department, iii) listed offences, and iv) prescribed penalties. The act also made provisions for establishing protected areas. It provisioned penalties for damaging or removing forest products from national forests without official permission of the government. It also spelled out for scientific survey of forest resources of the country. Following the Forest Act of 1961, Forest Protection 
Act (Special Provision) 1967 was launched that provisioned strict penalties for illegally collecting timber and forest products from national forests. Importantly, illegal collection of forest and forest encroachment was considered a state crime. The forest officials were given more power to take and recommend action against illegal forest cutting and collecting forest resources. It provisioned for a new category of forests, Panchayat Protected Forest, which should be managed by local communities, religious institutions and individuals. The Village Panchayat could manage up to 125 hectares of degraded forest and 500 hectares of existing forest as Panchayat protected forest. For its operation, the operating rules were implemented in 1978 that gave right to village panchayats, the lowest administrative unit, to manage barren or degraded lands for forest production.

During the early 1990s, the government had realized the importance of long term forestry planning. The Master Plan for the Forestry Sector (MPFS) was prepared during 1986-88 and approved by the government in 1989 (HMGN/ADB/FINIDA, 1988). The 25 year long term plan aimed to i) meet the people's basic needs for forest products on a sustainable basis, ii) conserve ecosystems and genetic resources, iii) protect land against degradation and other effects of ecological imbalance, and iv) contribute to local and national economic growth. The Master Plan provisioned for community and private forest and focused to establish community forest and forest user group (FUG) as a local management body of the community forest. Importantly, the Plan recommended to handover all accessible forests to local communities as per their willingness and capacity to manage it. It also made provision to have the operational plan of forest management by communities as a prerequisite to hand over forests to the community. In accordance with the aspiration of MPFS, the new forest act, Forest Act 1993 was promulgated.

The forest act 1993 divided the forest into five categories. These were community forest, leasehold forest, government-managed forest, religious forest, and protected forest. Among them, highest priority was given to community forestry. It defined community forest as the forest collectively managed by local villagers who organize themselves into a forest user group (FUG) and manage forest according to negotiated and approved management agreements with District Forest Office. It also defined community forest user group (CFUG) as a self-governing autonomous body with the right to use and manage the designated forest independently in accordance with the agreed management plan. The process for creating user groups and their rights were provisioned in Forest Regularities 1995. The forest act of 1993 was amended in 1999 and made a mandatory provision to invest its 25 percent income for forest conservation and development activities. Following the 1993 act, the Forest Sector Policy 2000 was launched. Its major objectives were to meet people's basic daily needs of forest products and to 
contribute to food production through better interaction between forestry and farming sectors. It aimed to protect land from degradation by soil erosion, desertification and various ecological disturbances. It emphasized conservation of bio-diversity and genetic resource and finally aimed to contribute to the growth of local and national economies. The policy also clearly focused to conserve and handover the forest patches of Tarai and Inner Tarai forest to community for its sustainable management and ensure 25 percent income from $\mathrm{CF}$ to local development.

The 25 year long master plan for forest sector that was implemented in 1989 was over in 2011. So the Ministry of Forest and Soil Conservation has prepared a draft for forest sector strategy 2012-2022. The draft plan is based on eight guiding principles including sustainable management of ecosystem services, improved forest governance, private sector engagement, and climate change mitigation. The draft plan aims to bring 60 percent of the total forest area under community forest. It aims to manage at least 50 percent of the Tarai forest effectively (MFSC, 2014).

\section{Changing forest coverage of Nepal}

The government of Nepal has conducted several forest surveys since 1963-64. Since then the forest coverage has been changing over the time (see Table 1). The first forest survey was done in the period from 1963 to 1967. Based on this survey, the total forest area of the country was 6.4 million ha in 1964. It was 45.5 percent of the total area of the country. The Water and Energy Commission Secretariat (WECS) also estimated the forest and shrub area for the same period (1964-65). The results showed 6.5 million hectare forest area. Out of it, 3.9 million ha in the Hill and mountain, 1.7 million ha in the Chure and 0.8 million ha in the Tarai (HMGN/ADB/FINIDA, 1988).

Table 1: Forest coverage of Nepal in different period (1963/64 - 2015)

\begin{tabular}{|c|c|c|c|c|c|c|}
\hline Types & $\begin{array}{c}\text { FRS }^{1} \\
(1963 / 64)\end{array}$ & $\begin{array}{c}\text { LRMP }^{2} \\
(1978 / 79)\end{array}$ & $\begin{array}{c}\text { NRSC }^{3} \\
(1984)\end{array}$ & $\begin{array}{c}M{ }^{4} F S^{4} \\
(1986)\end{array}$ & $\begin{array}{l}\mathrm{NFI}^{5} \text {, } \\
\text { DFRS } \\
(1999)\end{array}$ & $\begin{array}{l}\text { DFRS }^{6} \\
(2015)\end{array}$ \\
\hline Forest & 45.5 & 38.0 & 35.9 & 37.4 & 29.0 & 40.36 \\
\hline Shrub & & 4.7 & - & 4.8 & 10.6 & 4.38 \\
\hline Total & 45.5 & \begin{tabular}{|l|}
42.7 \\
\end{tabular} & 35.9 & 42.2 & 39.6 & 44.74 \\
\hline
\end{tabular}

FRS: Forest Resources Survey, 2. LRMP: Land Resource Mapping Project, 3.NRSC: National Remote Sensing Center of Nepal, 4. MPFS: Master Plan for the Forestry Sector, 5. NFI: National Forest Inventory, 6.Department of Forest Resource and Survey.

Source: DFRS, 1999; DFRS, 2015. 
Another forest survey at national scale was conducted by the Land Resource Mapping Project (LRMP, 1978/79). The survey was conducted during 1977 to 1984 . As per the survey the total forest area of the country was 6.3 million hectares that was 42.2 percent including the 4.7 percent shrub area. Out of it, Mountain and Hill had 4 million ha forest followed by 1.7 million ha in the Chure and 0.6 million ha in the Tarai (LRMP, 1989).

The Master Plan for the Forestry Sector (MPFS) also did a forest survey in 1986. It was based on the LRMP information and forest inventory data from Forest Survey and Research Office. Its aim was to update the forest coverage change that occurred during the intervening period of LRMP - 1977 to 1984. According to the survey the total forest area was 42.2 percent including 4.8 percent shrub land. The results showed a small increase in forest area in the Hill and Mountain and decrease in the Tarai (MPFS, 1989a). National Forest Inventory (NFI) 1994 was another survey that started in the early 1990s and completed in 1998. Its base year was 1994. As per the survey, the total forest area of the country was 39.9 percent including 10.6 percent shrub land. The Department of Forest did another survey covering the period between LRMP (1978/79) and NFI (1994). The result showed that the total forest area was decreased by 24 percent over a period of 15 years. The annual rate of forest loss was 1.6 percent. Importantly, the shrub area was increased by 126 percent, which showed the high rate of forest degradation (DFRS, 1999).

The government has also done a separate forest survey of 20 Tarai districts. The survey started in 2010 and completed in 2012. Out of the total land area of Tarai $(2,016,998 \mathrm{ha})$, forest cover area was 411,580 ha (20.41\%) and Other Wooded Land (OWL) covered area was 9,502 ha $(0.47 \%)$. The survey also concluded that the Tarai forest had declined by 16,500 ha from 2001 to 2010 . The total forest coverage loss from 1991 to 2010 was $32,000 \mathrm{ha}$. The annual forest decreasing rate was 0.44 percent for the period of 20012010 and 0.40 percent for the periods of 1991-2010 (DFRS, 2014).

The most recent forest survey of Nepal stems from 2010-2014. As per the survey, the total forest area of the country is 5,962,038 ha (40.36\%) and 647,892 ha (4.38\%) is shrub land (DFRS, 2015). The spatial distribution of forest by ecological region is uneven. The highest percentage of forest is in Hill (60.8\%) followed by Mountain (32.3\%), and Tarai (6.9\%). Out of 75 districts of Nepal, there are 12 districts with forest coverage above 60 percent. Importantly, there are 10 districts located in eastern Tarai and north western Mountain regions (see Figure 1) where forest coverage is below 10 percent of the total area of the district. Furthermore, the total forest area also includes the forest within the protected areas. At present, 23.39 percent land (34420.13 Sq. Km) has Protected Area 
status (MoF, 2016). Out of the total forest area in 2015 (5,962,038 ha) about 17 percent is within the protected areas (Table 2).

Table 2: Forest cover by ecological region and protected areas of Nepal

\begin{tabular}{|c|r|r|r|r|r|}
\hline \multirow{2}{*}{ Region } & \multirow{2}{*}{ Outside PAs } & \multicolumn{2}{|c|}{ Protected areas (ha) } & \multirow{2}{*}{ Total } & \multirow{2}{*}{ \% of total } \\
\cline { 3 - 4 } & & \multicolumn{1}{|c|}{ Core area } & Buffer zone & & 32.3 \\
\hline Mountain & $1,345,309$ & 459,240 & 118,360 & $1,922,909$ & 60.8 \\
\hline Hill & $3,269,467$ & 263,419 & 94,664 & $3,627,550$ & 6.9 \\
\hline Tarai & 314,660 & 69,847 & 27,074 & 411,580 & 100.0 \\
\hline Total & $4,929,436$ & 792,506 & 240,098 & $5,962,039$ & \\
\hline & 82.7 & 13.3 & 4.0 & 100.0 & \\
\hline
\end{tabular}

Source: Calculated based on DFRS, 2015.

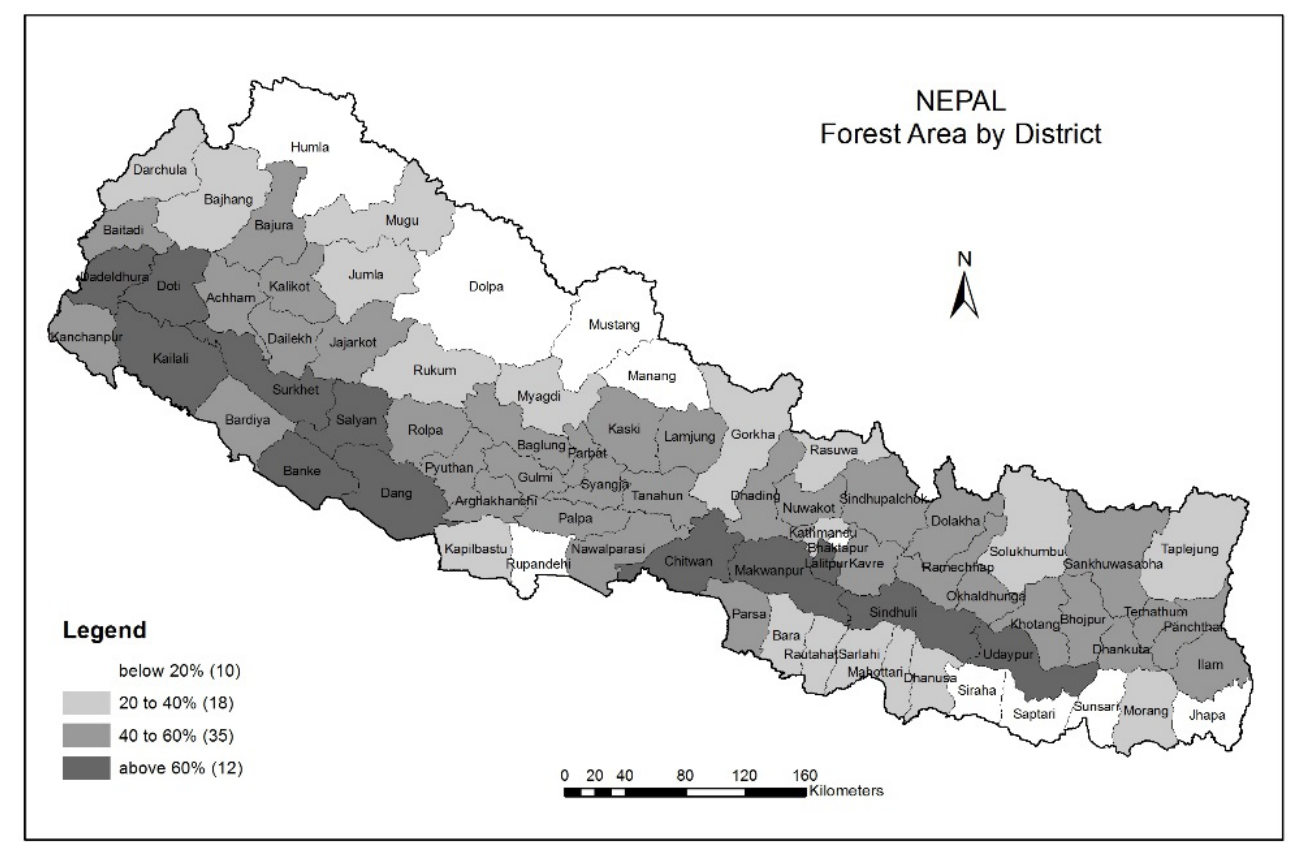

Figure 1: Forest coverage by district, 2015

The community forest (CF) program started after the forest act 1993. At present there are 18960 community forest user groups (CFUG) in Nepal. They comprise 1798,733 hectares area and 2,392,755 households (DoF, 2015-16). In other words it covers about 
30 percent of the total forest area and 44 percent of the households of the country. The community forest is in all districts except Mustang. Out of the total CF area, 15 percent is in Mountain, about 65 percent in Hill and 20 percent in Tarai. CF covers about 14 percent of the total forest area of Mountain, 32 percent of Hills and 87 percent of Tarai. The per household CF area is 0.75 hectare at the national level. While at the regional level, the per household CF area is 0.92 ha in Mountain, 0.78 ha in Hill and 0.6 ha in Tarai (DoF, 2015-16).

\section{Changing demographic characteristics}

Nepal's population size has been increasing rapidly. The total population of the country was 8.2 million in 1954 that reached to 18.5 million in 1991 and 26.5 million in 2011. The growth rate also remains high until 2001 and thereafter it has gradually declined. In each census from 1952/54 to 2001 the annual population growth rate remains above two percent. The highest growth rate ( 2.62 percent) was in 1981 . The rate has started declining after 2001 and maintained 1.35 percent in 2011 (see Table 3).

Table 3: Population size and growth rate of Nepal (1952-2011)

\begin{tabular}{|c|c|c|c|c|c|c|c|}
\hline Census Year & $1952 / 54$ & 1961 & 1971 & 1981 & 1991 & 2001 & 2011 \\
\hline \begin{tabular}{|l|} 
Population \\
Size \\
\end{tabular} & 8256.625 & 9412996 & 11555983 & 15022839 & 18491097 & 23151423 & 26494504 \\
\hline \begin{tabular}{|l|} 
Population \\
Growth Rate
\end{tabular} & 2.27 & 1.64 & 2.05 & 2.62 & 2.08 & 2.25 & 1.35 \\
\hline
\end{tabular}

Source: CBS, $2003 \& 2012$.

Nepal has diverse topography which is divided into Mountain, Hill and Tarai regions. These ecological regions shares 35,48 , and 17 percent area of the country respectively. While in terms of population, there is an unequal distribution. In the latest population census of 2011, Mountain, Hill, and Tarai share 6.7, 43.0, and 50.3 percent of the total population (CBS, 2012) while the share of population in these regions was 9.9, 52.5, and 37.6 percent respectively in 1971(CBS, 2003). The population growth rate of Tarai remains far higher compared to Mountain and Hill in each census after 1961. For instance, the population growth rate of Tarai was 2.39 in 1971, 4.11 in 1981, 2.62 in 2001, and 1.72 in 2011. In the case of Hill region, the growth rate was 1.85 in 1971 that became 1.61 in 1981, 1.91 in 2001, and 0.99 in 2011. While in the Mountain the growth rate was 1.35 in 1981 that became 1.57 in 2001 and 0.54 in 2011 (CBS, 2003, 2012). In this way, both population size and growth rate remains higher in Tarai. 
The high population growth in Tarai is attributed to migration from Mountain and Hill regions. In each census from 1971 to 2011, the net migration from Hill and Mountain has contributed about 10 percent to the total population of Tarai. The percent of net migrants to Tarai was about four hundred thousand in 1971 that reached to nine hundred thousand in 1991 and crossed one million in 2001 and 2011 census (see Table 4).

Table 4: Net migration by ecological region, 1971-2011.

\begin{tabular}{|r|r|r|r|r|}
\hline \multirow{2}{*}{ Year } & \multicolumn{3}{|c|}{ Ecological region } & \multicolumn{1}{c|}{$\begin{array}{c}\text { \% of migrants to total } \\
\text { population of Tarai }\end{array}$} \\
\cline { 2 - 4 } & Mountain & \multicolumn{1}{c|}{ Hill } & \multicolumn{1}{c|}{ Tarai } & 9.2 \\
\hline 1971 & $-39,959$ & $-359,966$ & 399,925 & 10.5 \\
\hline 1981 & $-261,467$ & $-424,711$ & 686,178 & 10.6 \\
\hline 1991 & $-161,655$ & $-753,923$ & 915,578 & 9.7 \\
\hline 2001 & $-255,103$ & $-830,759$ & $1,085,862$ & 8.0 \\
\hline 2011 & $-349,132$ & $-722,456$ & $1,071,588$ & \\
\hline
\end{tabular}

Source: CBS, 2003; Suwal, 2014.

\section{The changing explanations on deforestation}

Nepal's forest policy has changed several times from 1957 to until today and these changes are reflected in the forest area of the country. A very strict policy of forest nationalization was adopted in 1957 followed by the provision of Panchayat forest in 1967 in which the Village Panchyant could manage a limited degraded area. The nationalization policy continued until 1993. The forest act of 1993 is a milestone in the history of forest management of Nepal as it provisioned for community participation in forest management. With these changes in policy, Nepal's forest area has also changed from 45 percent during 1964 to 29 percent in 1994 and again increased to 40 percent in 2015. Not only in Nepal but the paradigmatic shift in forest governance has also taken place in many developing countries during the nineties. The shift from top-down bureaucratic to participatory approach was in response to the high deforestation and inefficiency of state institutions in forest governance (Shahbaz et al., 2012). In addition to changes in forest policy several changes have taken place in the political system of Nepal from 1950 to present. The hereditary Rana rule was ended in 1950, the multiparty system was established in the country in 1951. The party-less Panchayat political system was started in1961 that continued to 1990 . The multi-party system restored in 1991. The Maoist conflict began in early 2000s and ended with peace accord in 2006. The country was declared democratic republic in 2007. The Constitution Assembly election held twice that finally prepared the present constitution in 2015. The changes in 
political system are also reflected in the existing development policy. With reference to the changing forest policy, we have tried to capture the major debates on deforestation based on the literature primarily of the forest nationalization phase from 1950 to 1990 and participatory forest management phase after 1990 in general.

\section{The major debate on deforestation during forest nationalization period}

Early publications on deforestation presented a dramatic picture of mountain degradation due to deforestation and mismanagement of land by upland farmers. Robbe was one of the first who presented a rapid land degradation in the Middle Hills of Nepal in 1954 (Robbe, 1954). His analysis concluded with large-scale erosion of soils in the mountains. The soil ended up on the southern plains causing sand-casting and other problems there, and a shrinking of cultivable acreage and forested area in the mountains. Some argued wittingly that Nepal ought to put forth land claims in the Ganges-Brahmaputra estuary in the Bay of Bengal since it was Nepalese soils that formed new islands there.

The UN conference on the Human Environment in Stockholm in 1972 took Robbe's point further. Conference participants pointed to accelerating degradation and warned against the development of semi-desert type ecology in the hilly region of Nepal. The international debate soon entered into Nepalese politics. In a report from the National Planning Commission of Nepal (NPC,1974), the arguments of the Stockholm Conference were reflected. The most influential event came to be the 1974 Munich Conference on Mountain Environment where several papers managed to produce a sensation on a global scale. In particular, Eric Eckholm's presentation found resonance in global academia, in development policy circles, and in the media.

Eckholm's findings first appeared in Science in 1975. His book titled Losing Ground came in 1976 and presented a dramatic scenario of Himalayan deforestation and degradation by appointing population growth to be the major cause of upland deforestation and erosion. He claimed that mountain farmers cleared forest to meet the increasing demand of agricultural land for food production and also for firewood. Firewood was claimed the main source of energy for which mountain farmers cut green trees. His book became the dominant publication of this phase. Eckholm claimed that

...there is no better place to begin an examination of deteriorating mountain environments than Nepal. Population growth in the context of a traditional agrarian technology is forcing farmers onto ever steeper slopes, slopes unfit for sustained farming even with the astonishingly elaborate terracing practiced there. Meanwhile, villagers must roam 
farther and farther from their homes to gather fodder and firewood, thus surrounding most villages with a widening circle of denuded hillsides. Topsoil washing down into India and Bangladesh is now Nepal's most precious export, but one for which it receives no compensation. . .. silt load threatened the viability of an Indian diversion dam and irrigation project on the Koshi River... . ....... the country would by now be in the throes of a total economic and ecological collapse (Eckholm, 1976: 76-82).

However, almost two decades before Eckholm, Furer Haimendrof (1956) mentioned about the cultivation on marginal land and population pressure on the hills surrounding Kathmandu valley that pushed local people to involve in portering along the mountain paths (p.117). Hitchcock (1966) is perhaps the first who particularly stated the population pressure on the land a decade before Eckholm:

With increasing pressure on the land due to the growth in population, the ... the emergent money economy and intensification of trade have come new pattern... The disappearance of vacant, cultivated land, combined with increased population has pushed more and more farms below the level of marginal productivity (Hitchcock, 1966 cited in Fricke,1993:199-200).

The deforestation of Himalaya was initially presented as an outcome of population growth and concomitant pressure on natural resources. The increasing rate of population growth (Table 3) was taken as an evidence of the need for more agricultural land for subsistence purposes and for firewood that resulted in forest clearance, soil erosion, and landslides in the uplands.

Decreasing soil fertility and crop productivity due to the loss of fertile topsoil urged farmers to clear more land in order to feed a stable number of people, and even more so with a growing population. Upland landslides and soil erosion resulted in flooding and sedimentation downstream. This process became known as the 'Vicious Circle' of population growth, deforestation, and degradation. Influential institutions like the World Bank and the World Watch Institute claimed that the forest of Nepal would disappear by 2000 resulting in catastrophic conditions in terms of local livelihood (see Ives, 2006). This claim was sustained and became mainstream science. Several publications also identified poor management of rain-fed land (bari) as one of the major causes of degradation commonly observed throughout Nepal Himalayas (ADB, 1982; 
Shrestha, 1994). In short, too many environmentally ignorant farmers looking for new land to cultivate were appointed to be the adversaries of a sound development.

However, after the second half of the 1990s, a new explanation emerged on deforestation. Several publications (Thompson and Warburton, 1985; Mahat et al., 1986; Blaikie, 1985; Blaikie and Brookfield, 1987; Ives and Messerli, 1989) challenged the view that population growth caused deforestation and land degradation. The most influential event of this criticism was the Mohonk conference in 1986, and Ives and Messerli's book Himalayan Dilemma which came in 1989. These all accepted a massive deforestation in Nepal but it was not due to the ignorant hill farmers and population growth. These authors claimed that the historical processes of nation building of Nepal, government policy, the interests of the regime, and most importantly geo-phycially and climatically fragile environment of the Himalayas were the major causes of deforestation.

Nepal was divided into the number of principalities before the unification of the country that began in 1744 and ended after the taking of state power by the Rana rulers in 1846. The unification campaign demanded huge resources to cover military expenditure that could hardly be managed without exploiting revenue generating resources. Those resources were the Tarai forest and agricultural land, wild animals, herbs, and the trade routes between India and China (Regmi, 1999a, 1999b). The government motivated individuals to convert forest land into agriculture so that state revenue could be increased through land tax collection and food production could also be increased (Wallace, 1981; Mahat et al., 1986). This policy of converting forest to agricultural land was encouraged in the hereditary Rana dynasty. The Rana ruler appointed talukdars (village headmen) in Mountain and Hill regions and had given responsibility of regulating forest by converting into farms land and collection of land taxes (Mathema et al., 1999). Rana initiated jimidari system in Tarai in 1861, under which jimidars and patwaris (local government functionaries), were authorized as the local tax agents within their designated areas and gave exclusive power to clear the forest in order to collect taxes (Regmi, 1976). In addition, Rana rulers had granted Tarai forest land to Rana family members known as Birta land and to the high ranking government officials known as jagir in which the recipients had exclusive right to convert it to farmland and use it for their own benefit without paying taxes to the country (Hobley, 1985; Shrestha, 1996; Guthman, 1997). The Tarai forest was little disturbed until late 1920. Later it was extensively cleared for farmland and timber was explored to India to meet its increasing demand for expansion of railway networks and other purposes. By 1950, one-third of the total forests was under Birta tenure in Tarai and 75 percent of that belonged to the Rana family (Regmi, 1999b; Joshi, 1993). 
The Panchayat system (1961-1990) in its earlier phase initiated a policy to develop the Tarai as an important region of cereal grains and commercial crops (Bajracharya, 1993). The deforestation primarily took place in Tarai due to rapid migration from Hill and Mountain to Tarai (see table 4) that was initiated by the government after establishing Nepal Resettlement Company (NRC) in 1964. The eradication of malaria from the Tarai in 1959 also encouraged this policy. The resettlement program alone cleared 103,968 ha of forest in the Chure and Tarai between 1950s to the mid 1980s (HMGN/ADB/ FINIDA, 1988). The aim of the resettlement program was to distribute land to landless, flood and landslide victims but the Panchayat supporters also got benefits and more area was encroached illegally (Pokhrel, 1997).

During the forest nationalization period, access to forest resources remained with the state. Consequently, people felt no responsibility for its management. Nationalization in effect transformed the forests from a 'common property resource' to an 'open access resource' (Ostrom, 2008) and deforestation rocketed. Several forestation programs in all the country's 75 Districts were launched, but despite repeated efforts, forest coverage did not increase in line with the government's plan. On the contrary, forest coverage continued to decrease. The forest coverage was only 29 percent in 1994 and about 10 percent was under shrub land which was actually degraded forest. In addition to these processes and interest of the existing regime, Ives and Messerli (1989) systematically deconstructed the crisis scenario presented by Eckholm. They summed up the scenario in eight points and called it the 'Theory of Himalayan Environmental Degradation' (THED). Importantly, they reminded readers that Himalaya is the youngest mountain system on the earth. It is tectonically active with a dissected landscape, an extremely high relative relief, and steep slopes. The entire region has monsoon climate with a short and intense summer rainy season, and extreme weather events are common. They further systematically examined rural land management and firewood collection practices of Hill farmers and concluded that they were not the alleged culprits as claimed earlier; rather, their activities were founded on sound environmental principles. In this way, physical intervention into fragile Himalayan environments and government policy became the dominant causes of deforestation.

\section{The major debate on deforestation after 1990}

The scenario of explaining Himalayas as 'fragile environment' has persisted as a label of Himalaya until this day, but a major shift of focus took shape after 1990. Many important events related to environment and development at wider scale took place during late 1990s. The most remarkable among them were the publication of the Brundtland report on sustainable development (1987), the almost universal acceptance of 
bottom-up approach in development efforts, the feminist movement, and the importance of biodiversity that was stated in Agenda 21 at the Rio Conference in 1992. Since then the international environmental discourse has not only shaped environmental policy in Nepal but indeed the overall development policy of the country. On the national level, the forest act 1993 was promulgated and it became the major turning point. The act provisioned of handing of forest to local community for its utilization and management. It again recognized the traditional forest management system that was broken by the forest nationalization act (Sherpa et al., 1986; Malla, 2001). In addition, a few very influential papers (Blaikie, 1995; Guthman, 1997; Forsyth, 1998; Balikie and Muldavi, 2004; Gurung, 2005) critically reviewed the previous explanations and highlighted the social and cultural aspects of degradation on a wider scale than before.

The forest coverage data show that the total forested land had not changed much until 1999 as it was just the beginning phase of community forest program. The gloomy predictions of the 'crisis' scenarios as claimed by Eckholm was already refuted. Later, a case study from Dhankuta District of eastern Nepal showed an increase in forest coverage between 1978 and 1990 due to regeneration and plantation. The forested area, crown density, and mean height of trees had improved over the period according to the surveys (Virgo and Subba, 1994). Human population has continuously increased (Table 3) but the forest has not decreased as it was claimed by Eckholm and others. Instead, it was argued that forest cover has gradually increased after 1999 as a result of community forestry. By 2015, the forest area of Nepal had become 40 percent. The degraded forest area was decreased to about 4 percent (Table 1).

Harka Gurung published a working paper entitled Ecological Change in Nepal: A Native Interpretation in 1981 in which he appointed the prevalent poverty as a main cause of degradation. Ten years later his point was taken up by the National Planning Commission of Nepal. In the Five Year Plan for 1992-97 one of the major objectives was to reduce poverty. Many programs were formulated in the forestry sector for that end. The Plan clearly stated that an increasing percentage of people living below the poverty level was a major cause of environmental degradation. The Ninth Five-year plan (1997-2002) gave first priority to poverty alleviation and formulated programs for providing economic opportunities for poor people and encouraged their participation in development activities through different sectors, including forestry. This policy was continued in the Tenth Five-year plan (2002-2007). The successive five year plan also carried over the major objective of the Ninth plan and considered forest as a major sector for employment and income generation. The forest sector policy 2010 focused on linking forestry, farming and livelihood for income and employment generation. The recent Fourteenth Plan (2016-2018) also sought to reduce poverty and focused on 
participatory management of forest and buffer zones of the national parks, and declare 2014-2024 as the 'forest decade' with the slogan 'forest for prosperity'. A Poverty Alleviation Fund (PAF) was established with the support from various donor agencies and several income generating, employment producing, and empowerment programs have been implemented. PAF emphasized the substantial role of forest resources in poverty reduction as well as the other way around, that poverty influences forests.

The community forest management practice after 1990 has been successful particularly in Hill region as it increased forest coverage, improved livelihoods opportunities for forest dependent people, developed local institutions, and improved ecological conditions of forest (Ojha and Kanel, 2005; Jackson et al., 1998; Gautam et al., 2002; Adhikari et al., 2007; Kanel, 2008; Tachibana and Adhikari, 2009; Pandit and Bevilacqua, 2011; Virgo and Subba, 1994; Collett et al., 1996; Jackson et al., 1998; Gautam et al., 2003). A few recent publications (Niraula et al., 2013; Sharma et al., 2014; Poudel et al., 2014; Jaquet et al., 2015; Poudel et al., 2015) from various parts of Nepal confirm that forest coverage has increased in this millennium. The result of this policy turned out to be positive as the forest coverage again increased after years of decrease (Table 1). The alleged forest growth justified the focus on local participation. Community forestry became the mantra of the period.

But did the explicit focus on poverty alleviation really have any effects? Data reveal a substantial decrease in poverty. The percent of people living below the poverty line was 41.8 in 1996, which decreased to 30.9 percent in 2004 and further to 24.8 percent in 2008. By 2015, about 19,000 community forest user groups have been formed throughout the country and 30 percent of the country's total forest area is under the Community Forestry programe (DoF, 2015-16).

Farmers were no longer accused of being the bad guys in the 'Himalayan dilemma' (Ives and Messerli, 1989). Quite the opposite, they were perceived as knowledgeable users of natural resources whose experience should be the foundation of forest management (also see Aase, 2017; Koirala, 2017). Forests would be far better if top-down control mechanisms were substituted by bottom-up management approach. The degradation that did go on was largely ascribed to natural causes, and a legacy of historical process of utilization and management rather than deforestation resulted in a lack of livelihood opportunities and poverty. 


\section{Shortcomings of the previous explanations}

Poverty is still considered to be the major cause of environmental degradation in Nepal and, concomitantly, environmental policies emphasize poverty alleviation programs. But in spite of this, and in spite of surveys that contend recent forest growth, the reality is probably that forest area decreased continuously during the latter half of the previous century. It decreased by 1.7 percent annually from 1978/79 to 1994 (DFRS, 1999). The annual rate of forest coverage decrease in the case of 20 Tarai districts always remains high as it was decreased by 15 percent from 1978/79 to 1990/91 (DoF, 2005). The annual rate of decrease was 0.44 percent for the period of 2001-2010 and 0.40 percent for the periods of 1991-2010 (DFRS, 2014).

As Table 1 reveals, Department of Forest Resources and Surveys (DFRS) claimed a forest coverage of about 40 percent in 2015, but this number is highly questionable. DFRS applied a methodology that differed from those used in previous surveys in terms of data sources, scale of source data for mapping, geographical coverage of the survey, minimum area covered, and the methods of analysis. Small forest patches which were excluded in the previous surveys were included in the 2015 survey carried out by DFRS (Niraula, 2013; DFRS, 2015). This survey is based on high resolution satellite image (Rapid Eye MSS satellite imagery), secondary images (Google Earth images, ancillary maps (LRMP and topographical maps), and ground sampling and verification. Fragmented forest patches the size of less than 2 ha were included. The previous surveys were primarily based on aerial photographs of 1:20000 to 1:50000 scale and Landsat images of 30*30' meter resolution (HMG, 1973; LRMP, 1989; DFRS, 1999). The increased of forest coverage in 2015 is mainly due to inclusion of abandoned farmland as vast areas of formerly cultivated fields are left to regrowth by shrub and forest, mainly due to migration and lack of labor power in the villages and such lands can be reclaimed by farmers at any time and should not be counted as permanent forest (Poudel et al., 2014; Sharma et al., 2014; Jaquet et al., 2015). Thus, the surveys referred to in Table 1 are incommensurable.

The continued decrease of forest cover questions the last twenty years' focus on poverty alleviation. Poverty decreased substantially from 42 percent to 25 percent during 19962008 but, instead of increasing the forest coverage as expected, the recent years have witnessed continuously decreasing forests. Why is it so?

Water and Energy Commission Secretariat $(2010)$ and FAO $(2001,2006)$ have published forest coverage data of Nepal (Table 5). The figures of Table 2 and Table 5 (below) coincide in 1994, but in Table 5, FAO has noted decreasing forest coverage data for the 
years 2000 and 2005. A probable explanation to the diverging data is that actual forests have decreased while shrub areas are steadily increasing. If this is the case, it warns of the possibility of substantial forest degradation in the future.

Table 5: Changing forest coverage of Nepal according to FAO

\begin{tabular}{|l|r|r|r|}
\hline \multirow{2}{*}{ Category } & \multicolumn{3}{|c|}{ Forest type and coverage (\% of total landmass) } \\
\cline { 2 - 4 } & $\mathbf{1 9 9 4}$ & $\mathbf{2 0 0 0}+$ & \multicolumn{2}{|c|}{$\mathbf{2 0 0 5}$} \\
\hline Forest & 29.0 & 26.5 & 24.7 \\
\hline Shrub land & 10.6 & 11.9 & 12.9 \\
\hline Total & 39.6 & 38.4 & 37.6 \\
\hline
\end{tabular}

Source: WECS, 2010. + FAO, 2001; * FAO, 2006.

In the scientific literature, there is hardly any credible explanation of Himalayan degradation and deforestation for the period after 2000. But if we extend our context of analysis beyond Nepal, several new circumstances become salient. FAO (2006) has published comparative forest cover figures from selected Asian countries, namely China, India, Nepal, Pakistan, Sri Lanka, Bangladesh, and Bhutan. The figures show that there is negative change in forest coverage in Nepal, Pakistan, and Sri Lanka during 1990-2005. There are positive changes in Bhutan, China, and India while Bangladesh is more or less stable.

Sri Lanka and Pakistan have higher average incomes and less inhabitants below the poverty line than Nepal, but still they witness a similar rate of deforestation as Nepal does. This fact casts further doubt upon the recent conviction that poverty and deforestation are closely interlinked. What, then, could be a credible explanation to the findings of FAO? Like Nepal, Pakistan and Sri Lanka have been characterized by political instability and internal conflicts during the last 25 years. In contrast, the state and the governance system remain comparatively strong in India and Bhutan where forest coverage has improved. This fact directs our attention to the role of the state in environmental governance. How is the situation in Nepal in that respect?

Since long back Nepal has been passing through the stage of political transitions as presented earlier. The Maoist insurgency (1995-2005) is the latest that severely hampered the functioning of government bodies and NGOs across the country (MFSC, 2014). The decade-long internal conflict killed 15,000 people. Thousands were displaced and hundreds of people disappeared. The conflict, according to USAID (2006), broke down institutional mechanisms, rules and regulation on the grass-root level causing forests to be mismanaged. Timber and other forest resources became the economic foundation 
of the Maoist insurgents and forests became the place of hiding and operational bases. In that situation it is obvious that the Community Forest User Groups (CFUG) could not function properly. Moreover, political instability became so severe that the Central Government changed 16 times from 2000 to 2015. (https://en.wikipedia.org/wiki/List_ of_Prime_Ministers_of_Nepal accessed 27 April 2016).

Although the community forest has substantially contributed to increasing forest coverage, problems arise within the community forestry system. The major challenges it faces are the issues of good governance, livelihood upliftment and sustainable forest management (Kanel and Niraula, 2004). It has in fact limited participation of poor and disadvantageous group in resource governance and is thus unable to manage the distribution and operation of power amongst different types of resource users within CFUGs (Adhikari et al., 2014). Because of such issues a rapid decline in forest coverage has been observed in the Nepalese part of the Kailash landscape in eastern Nepal that covers 13,289 square kilometers area where forest area has decreased by 9 percent and cropland has increased by 12 percent from 1990 to 2009. The deforestation is mainly due to the lack of appropriate approaches of monitoring and assisting community and local forest stakeholders in forest management (Uddin et al., 2015). Importantly, its success in Tarai is in question as forest area under CF in the Tarai is more degraded as compared to other types of forest (Nagendra, 2002).

The country has had no local level elected body since 2000. The Maoist conflict weakened local level government and other institutions which negatively affected forest conservation (MFSC, 2014). Government officials and representatives have been illegally involved in deforestation in government managed forests as well as in community forests. Indeed, higher government employees and politicians have become the modern subbas and mukhyas. Timber has been illegally extracted and smuggled over the open border to India where timber is in high demand due to a strict Indian forest policy (http://www.bbc.com/news/science-environment-11430622 accessed on June 30 2015). Severe forest degradation has been observed in Chure forest from which India is reached in a couple of hours (Siwalik range; Kantipur Daily http://www.ekantipur.com/ the-kathmandu-post/2012/01/24/nation/deforestation-under-political-clout/230789. $\mathrm{html}$ accessed on June 30,2015). The internal conflict was resolved in the peace accord in 2006. Nepal experienced continuous disagreement sometimes amounting to violence over the new Constitution that was finally sanctioned in 2015. But immediately after the declaration of the Constitution, India initiated an unofficial blockade that resulted in severe shortage of cooking gas and petroleum products that compelled people to use firewood for cooking, even in urban areas. The blockade added pressure on forests as 
the Government had to supply firewood from lowland Tarai to Kathmandu and other cities.

Not only political instability but also corruption has contributed to forest degradation. Nepal has fallen on the ranking list of Transparency International from rank 97 to 120 in 2016. In comparison, the scores of other South Asian countries, with some exceptions, have improved somewhat in the same period (see http://www.transparency.org/cpi2015 accesses on 28 April 2015). It is our contention that socio-political conflict, limited livelihood opportunities, lack of good governance, and persistent corruption have contributed substantially to deforestation and degradation in this millennium. These are circumstances that have been more or less absent in the previous discourse on the Himalayan environment.

\section{Conclusion}

Nepal's forest management has passed through strict centralized approach to community participation from 1957 until today. Several changes in political systems have been adopted in the last six decades. With changing political system, the forest policies are also changed and these changes are reflected through the promulugation of acts, rules, and regulations. The pre- nationationalization phase was marked by the unification process of the country that lasted from 1744 to 1846 . The forest resources, particularly timber, was the most important source of income for managing the cost of military expenses in that period. The country was ruled by Rana family from 1846 to1950. During the Rana period the forest was granted to Rana family and royal loyalties and allowed government functionaries to reclaim the forest for the purpose of state revenue. Beginning with the forest nationalization act 1957, the strict ban on forest was remained until the beginning of community participation in 1990. People felt no responsibility in forest management and thus a rapid deforestation took place in Hill and especially in Tarai. After the community participation, forest coverage has increased but problems arise in CF governmance and benefit sharing.

There are various understandings about the deforestation of Nepal Himalayas. During the nationalization period it was explained by population growth becoming hegemonic during the early post-Second World War period. It was modified somewhat during the latter part of the 1990s when the hill farmer ceased to be the appointed culprit in the alleged vicious circle of degrading soils and need for ever more forests to be cleared. Instead, blame was put on human interferences in the 'fragile' Himalayan environment. The interplay between the young geo-physical formation, unique monsoon climate, the historical process of nation building, and interest of the regime and development 
activities, were accepted as the major causes of deforestation. In this millennium, poverty and lack of livelihood opportunities became the dominant explanation. None of the previous explanations give due attention to bad governance, internal conflict, corruption and concomitant institutional failure that must be included in order to understand the present situation.

The debates on forestry in Nepal reflects changing fashions in international discourses on development and environment. But in contrast to the African discourse that has largely been framed on development policies (Leach and Mearns, 1996), forest management in Nepal has been viewed in a broader context that involves state interventions and activities of multiple stakeholders. In that sense the various understandings of Himalayan deforestation not only reflects changing fashions in the international development discourse, but also actual realities on the ground. The much criticized population pressure focus of the early phase was probably valid in the 1960s and -70s. The massive out-migration of villagers started around that time which substantially eased the pressure on natural resources and left the 'theory' redundant. Today, abandoned farmland has become a problem rather than the clearing of more land. In that sense, the harsh critique that came up in the late 1980s and later (Thompson, 1985; Ives and Messerli,1989; Ives, 2006) was probably misplaced and unfair.

\section{References}

Aase, T.H. (2017). Are doomsday scenarios best seen as failed predictions or political detonators? The case of the 'Theory of Himalayan Environmental Degradation'. The Geographical Journal of Nepal, 10:1-14.

ADB. (1982). Nepal agricultural sector strategy study. Kathmandu: Asian Development Bank.

Adhikari, B., Williams, F., \& Lovett, J. C. (2007). Local benefits from community forests in the middle hills of Nepal. Forest Policy and Economics, 9: 464-478.

Adhikari, J., \& Dhungana, H. (2010). The state and forest resources: An historical analysis of policies affecting forest management in the Nepalese Tarai. Himalaya, the Journal of the Association for Nepal and Himalayan Studies, 29 (1): 43-56.

Adhikari, S., Kingi, T., \& Ganesh, S. (2014). Incentives for community participation in the governance and management of common property resources: The case of community forest management in Nepal. Forest Policy and Economics, 44:1-9. 
Bajracharya, D. (1983). Deforestation in the food/fuelwood context. historical and political perspective from Nepal. Mountain Research and Development, 3(3): 227-240.

Blaikie, P. (1985). The political economy of soil erosion in developing countries. London: Longman.

Blaikie, P. (1995). Changing environment or changing view? Geography, 80(3): 203214.

Blaikie, P., \& Muldavin, J. (2004). Upstrem downstream, China, India: The politics of environment in the Himalayan region. Annals of the Association of the American Geographers, 93(3):520-548.

Blaikie, P., \& Brookfield, H. (1987). Land degradation and society. London: Methuen.

Collett, G., Chhetri, R., Jackson, WJ., \& Shepherd, KR. (1996). Nepal Australia community forestry project socio-economic impact study. Canberra, Australia: ANUTECH Pvt Ltd.

CBS (2003). Population monograph of Nepal Vol I. Kathmandu: Central Bureau of Statistics (CBS).

CBS (2012). National population and housing census 2011 (National report). Kathmandu: Central Bureau of Statistics (CBS).

Chetri, RB. (2006). From protection to poverty reduction: A review of forestry policies and practices in Nepal. Journal of Forest and Livelihood, 5(1): 66-77.

Crooks, KR., Burdett, CL., Theobald, DM., Rondinini, C., \& Boitani, L. (2011). Global patterns of fragmentation and connectivity of mammalian carnivore habitat, Philosophical Transactions of the Royal Society B: Biological Sciences, 366 (1578): 2642-2651.

DFRS (1999). Forest Resources of Nepal (1987-1998). Kathmandu: Department of Forest Research and Survey (DFRS).

DFRS (2010). Forest resource assessment in Nepal: An assessment of data needs. Forest Resource Assessment (FRA) Nepal project. Kathmandu: Department of Forest Research and survey, GoN.(https://www.researchgate.net/file.PostFileLoader. html?id=5750793240485402b7395418\&assetKe access on Feb. 14, 2017).

DFRS. (2104). Terai forests of Nepal 2010-2012. Kathmandu: Department of Forest Research and Survey. 
Prem Sagar Chapagain \& Tor H. Aase / Changing forest coverage ...Vol. 13: 1-28, 2020

DFRS. (2015). State of Nepal's forests. Forest resource assessment (FRA) Nepal. Kathmandu: Department of Forest Research and Survey.

Dahal, D. S. (2014). Status and trends in forest and forestry development in Nepal: Major success and constraints. International Journal of Science, 3(5): 51-65.

DoF (2005). Forest cover change analysis of the Terai districts (1990/91-2000/2001).

Kathmandu: Ministry of Forests and Soil Conservation, Department of Forests, His Majesty's Government of Nepal.

DoF (2014). Forestry sector strategy for Nepal (Year .... From .... to) (http://www. sias-southasia.org/new/wp-content/uploads/2013/09/Forest-Sector-Strategy. pdf accessed on Mrch 10 2017)

DoF. (Department of Forest). (2015-16). Community forestry bulletin, Vol. 16. Kathmandu: Community Forest Division, Department of Forest, GoN.

Eckholm, EP. (1976). Losing ground: Environmental stress and world food prospects. New York: W W Norton.

FAO. (2001). Global forest resource assessment 2000. Rome: Food and Agriculture Organization of the United Nations.

FAO. (2006). Global forest resource assessment 2005. Rome: Food and Agriculture Organization of the United Nations.

FAO. (2009). Asia-pacific forestry sector outlook study II working paper series (working paper no. Apfsos ii/wp/2009/05) Nepal forestry outlook study. Bangkok: FAO. (http://www.fao.org/docrep/014/am250e/am250e00.pdf accessed on 20 April 2016).

Forsyth, T. (1996). Mountain myth revisited: Integrating natural and social environmental science. Mountain Research and Development, 18(2): 126-139.

Fricke, T.E. (1993). Himalayan households: Tamang demography and domestic processes. Varanasi: Pilgrims publishing.

Furer Haimendrof, CV. (1956). Ethnographic notes on the Tamangs of Nepal. Eastern Anthropologist, 9 (3-4): 166-177.

Gautam, AP., Webb, EL., \& Eiumnoh, A. (2002). GIS assessment of land use/land cover changes associated with community forestry implementation in the Middle Hills of Nepal. Mountain Research and Development, 22: 63-69. 
Gautam, AP., Webb, EL., Shivakoti, GP., \& Zoebisch, MA. (2003). Land use dynamics and landscape change pattern in a mountain watershed in Nepal. Agriculture, Ecosystems \& Environment, 99: 83-96.

Gautam, AP., Shivakotu, GP., \& Webb, EL. (2004). A review of forest policies, institutions, and changes in the resource condition in Nepal. International Forestry Review, 6(2): 136-148.

Gilmour, DA. (1997). Not seeing the trees for the forest: A re-appraisal of the deforestation crisis in the two hill districts of Nepal. Mountain Research and Development 8 (4):343-350.

Graner, E. (1997). The political ecology of community forestry in Nepal. Saarbrucken: Verl, Fur Entw, icklungspolitik.

Gurung, G. M. (1999). Migration, politics and deforestation in lowland Nepal. In H. O. Skar (Ed.) Nepal: Tharu and Tarai Neighbors. PP. Kathmandu: EMR.

Gurung, H. (1981). Ecological changes in Nepal: A native interpretation. An Occasional Paper 1. Kathmandu: New Era.

Gurung, H. (2005). Landscape change in Lamjung: Evidence from Nepal hills. Kathmandu: ICIMOD.

Guthman, J. (1997). Representing crisis: The theory of Himalayan environmental degradation and the project of development in the post Rana Nepal. Development and Change, 28: 45-69.

Hitchcock, J. T. (1966). The Magars of Banyan Hill. New York: Holt, Rinehart, and Winston.

Hobley, M. (1985). Common property does not cause deforestation. Journal of Forestry, 83:663-664.

HMG (His Majesty's Government). (1973). Forest statistics for the Hill region, 1973. Forest Resources Survey. Kathmandu: Forest Resources Survey Office, Department of Forestry, Nepal.

HMGN/ADB/FINNIDA. (1988). Master Plan for the Forestry Sector, Nepal: Main Report. Kathmandu: Ministry of Forests and Soil Conservation, HMGN.

Ives, J. D., \& Messerli, B. (1989). The Himalayan dilemma: Reconciling development and conservation. London/New York: Routledge. 
Prem Sagar Chapagain \& Tor H. Aase / Changing forest coverage ...Vol. 13: 1-28, 2020

Ives, J. D. (2006). Himalayan perceptions: Environmental changes and the wellbeing of mountain peoples, 2nd ed. Lalitpur: Himalayan Association for the Advancement of Science.

Jackson, WJ., Tamrakar, RM., Hunt, S., \& Shepherd, KR. (1998). Land use changes in two Middle Hills districts of Nepal. Mountain Research and Development, 18: 193-212.

Jaquet, S., Schwilch, G., Hartung-Hofmann, F., Adhikari, A., \& Sudmeier-Rieux, K. (2015). Does outmigration lead to land degradation? Labour shortage and land management in a western Nepal watershed. Applied Geography, 62: 157-170.

Joshi, A. L. (1993). Effects on administration of changed forest policies in Nepal. In: Policy and Legislation in Community Forestry. PP Proceedings of a Workshop held in Bangkok, Jan 27-29. Regional community Forestry Training Centre, Bangkok.

MoFSC (2001). Report of the joint technical review committee. Kathmandu: Ministry of Forest and Soil Conservation.

Kanel, K. R., \& Niraula, D. R. (2004). Can rural livelihood be improved in Nepal through community forestry? Banko Jankari, 14:19-26.

Kanel, K. R. (2008). So far so good: Next steps in community forestry. In: Ghate, R., Jodha, N.S., Mukhopadhyay, P. (Eds.), Promise, trust and evolution: Managing the commons of South Asia. PP New Delhi:Oxford University Press.

Koirala, H.L. (2017). Myth and reality of the eco-crisis in Nepal Himalaya. The Geographical Journal of Nepal, 10;39-54.

Leach, M., \& Mearns, R. (1996). Environmental change and policy: Challenging received wisdom in Africa. In The lie of the land: Challenging received wisdom on the African environment (pp. 11-27). Oxford: The International African Institute and James Curry.

LRMP. (1986). Land system report: Land resource mapping project. Canada: Kenting Earth Science.

Mahat, TBS., Griffin, DM., \& Shepherd, KR. (1986). Human impact on some forests of the Middle Hills of Nepal: Part 1. Forestry in the context of the traditional resources of the state. Mountain Research and Development, 6: 223-232. 
Malla, YB. (2001). Changing policies and the persistence of patron-client relations in Nepal: Stakeholders' responses to changes in forest policies. Environment History, 6 (2): 287-307

Mathema, P., Shrestha, KB., \& Sthapit, KM. (1999). Participatory forest management: implications for human resources' development in Nepal. In: Bhatia, A. (Ed.) Participatory Forest Management: Implications for Human Resources' Development in the Hidukush Himalayas, Volume V, Nepal.PP Kathmandu: International Centre for Integrated Mountain Development.

Molden, D. J., Shrestha, A. B., Nepal, S., \& Immerzeel, W.W. (2016). Downstream implications of climate change in the Himalayas. In: Biswas A., Tortajada C. (eds.) Water Security, Climate Change and Sustainable Development. PP Water Resources Development and Management. Singapor: Springer.

MFSC (1995). Forest act (1993) and forest regulation (1995). Kathmandu: Ministry of Forest and Soil Conservation, HMG/N.

MFSC (2000). Revised forestry sector policy 2000. Kathmandu: Ministry of Forests and Soil Conservation, Nepal.

MFSC (2014). Forestry sector strategy for Nepal (Draft version). Kathmandu: Ministry of Forest and Soil Conservation, Nepal (http://theredddesk.org/countries/ policies/nepals-forest-sector-strategy-2012-2022, accessed on February 7, 2017)

MoF (2016). Economic Survey: Fiscal Year 2015/16. Kathmandu: Ministry of Finance (MoF), GoN. (http://www.mof.gov.np/uploads/document/file/Economic\%20 Survey\%202015-16\%20-\%20English_20160812062624.pdf access on November 22, 2016).

MPFS (1989a). Master plan for forestry sector. Main report. Kathmandu: Ministry of forest and soil conservation, Nepal.

Nagendra, H. (2002). Tenure and forest condition. community forestry in the Nepal Tarai. Environmental Conservation, 29 (4): 530-539.

Niraula, R. R., Gilani, H., Pokharel, B. K., \& Qamer, F. M. (2013). Measuring impacts of community forestry program through repeat photography and satellite remote sensing in Dolakha district of Nepal. Journal of Environmental Management, 126:20-29. 
Prem Sagar Chapagain \& Tor H. Aase / Changing forest coverage ...Vol. 13: 1-28, 2020

NPC. (1974). Draft proposal of task force on land use and erosion control. Kathmandu: National Planning Commission.

Ojha, H. R., \& Kanel, K. (2005). 25 years of community forestry in Nepal - A review of fourth national workshop proceeding. Journal of Forest and Livelihood, 4 : 56-60.

Ostrom, E. (2008). The challenge of common-pool resources. Environment, 50(4): 9-20. (http://www.environmentmagazine.org/Archives/Back\%20Issues/JulyAugust\%202008/ostrom-full.html accessed on November 7 2015).

Pandit, R., \& Bevilacqua, E. (2011). Forest users and environmental impacts of community forestry in the hills of Nepal. Forest Policy and Economics, 13: $345-352$

Paudel, K. P., Tamang, S., \& Shrestha, K. K. (2014). Transforming land and livelihood: analysis of agricultural land abandonment in the Mid Hills of Nepal. Journal of Forest and Livelihood, 12(1): 11-19.

Pokharel, B. K. (1997). Foresters and villagers in contention and compact. Ph.D. thesis. University of East Anglia, Norwich, UK.

Poudel, N. R., Fuwa, N., \& Otsuka, K. (2015). The impact of a community forestry program on forest conditions, management intensity and revenue generation in the Dang district of Nepal. Environment and Development Economics 20 (2):259-281.

Regmi, M. C. (1976). Landownership in Nepal. Berkeley: University of California Press.

Regmi, M. C. (1978). Land tenure and taxation in Nepal. Kathmandu: Ratna Pustak Bhandar.

Regmi, M. C. (1988). An economic history of Nepal 1846-1901. Varanasi: Nath Publishing House.

Regmi, M. C. (1999b) [1978]. Thatched huts and stucco palaces: Peasants and landlords in 19th century Nepal. Delhi: Adroit Publishers (2nd reprint).

Regmi, R. C. (1999a) [1972]. A study in Nepali economic history, 1768- 1846. Delhi: Adroit Publishers (2nd reprint).

Regmi, RC. (1999b) [1978]. Thatched huts and stucco palaces: Peasants and landlords in 19th century Nepal. Delhi: Adroit Publishers ( ${ }^{\text {nd }}$ reprint). 
Robbe, E. (1954). Report on the government of Nepal on Forestry, ETAP report no 209. Rome.

Scott, C.A., Zhang, F., Mukherji, A., Immerzeel, W., Mustafa, D., \& Bharati, L. (2019). Water in the Hindu Kush Himalaya. In: Wester P., Mishra A., Mukherji A., Shrestha A. (eds.) The Hindu Kush Himalaya Assessment. PP Cham: Springer

Shahbaz, B., Ali, T., \& Awais, M. (2012). Perceived impact of participation in forest management on natural and social capitals in Manshera district of Pakistan. Journal of Animal and. Plant Science, 22:1167-1172.

Sharma, L. N., Vetaas, OR., Chaudhary, R. P., \& Maren, I. E. (2014). Pastoral abandonment, shrub proliferation and landscape changes: a case study from Gorkha, Nepal. Landscape Research, 39(1): 53-69.

Sherpa, M. N., Coburn, B., \& Gurung, C. P. (1986). Annapurna conservation area, Nepal: Operational plan. Kathmandu: King Mahendra Trust for Nature Conservation and World Wildlife Fund.

Shrestha, K. B. (1996). Community forestry in Nepal: An overview of conflicts. Discussion Paper Series No 96/2. Kathmandu: International Centre for Integrated Mountain Development.

Suwal, R. B. (2014). Internal migration in Nepal. In Population Monograph of Nepal, Vol I (pp.241-284). Kathmandu: Central Bureau of Statistics.

Tachibana, T., \& Adhikari, S. (2009). Does community- based management improve natural resource condition? Evidence from the forests in Nepal. Land Economics, 85 (1):107-131.

Thomson, M., \& Warburton, M. (1985). Uncertainty on a Himalayan scale. London: Routledge.

Uddin, K., Chaudhary, S., Chettri, N., Kotru, R., Murthy, M., Chaudhary, RP., Ning, W., Shrestha, SM., \& Gautam, SK. (2015). Changing land cover and fragmenting forest on the roof of the World: A case study in Nepal's Kailash sacred landscape. Landscape and Urban Planning, 141:1-10.http://dx.doi. org/10.1016/j.landurbplan.2015.04.003.

UNCED. (1992). Agenda 21: Program of action for sustainable development. Chapter 13. Place of Publication: United Nations Publications, 
Prem Sagar Chapagain \& Tor H. Aase / Changing forest coverage ...Vol. 13: 1-28, 2020

USAID (2006). Conflict over natural resources at the community level in Nepal: Including its relation to armed conflict. (http://www.forestrynepal.org/images/ publications/Conflict_over_NRM_Nepal.pdf accessed on June 30 2015).

USAID Nepal. (2012). Nepal biodiversity and tropical forestry analysis: prosperity, livelihoods and conserving ecosystems. Kathmandu: USAID.

Virgo, K. J., \& Subba, K. J. (1994). Land use change between 1978 and 1990 in Dhankuta district, Koshi hill, eastern Nepal. Mountain Research and Development, 14 (2):159-170.

Wallace, MB. (1981). Solving common-property resourceproblems: Deforestation in Nepal. Ph.D. thesis, Harvard University, Massachusetts: Cambridge.

WECS (2010). Energy Sector Synopsis Report 2010. Kathmandu: Water and Energy Commission Secretariat. 